\title{
Pengaruh Model Circ Berbantuan Notes Terhadap Minat Baca dan Hasil Belajar Mahasiswa PGSD Undiksha Singaraja
}

\author{
Ni Wayan Rati ${ }^{*}$, Ni Nyoman Rediani ${ }^{2}$ \\ 1,2 Jurusan Pendidikan Guru Sekolah Dasar Fakultas Ilmu Pendidikan Universitas Pendidikan Ganesha
}

\author{
A R T I C L E I N F O \\ Article history: \\ Received 20 August 2018 \\ Received in revised form \\ 9 September 2018 \\ Accepted 15 October 2018 \\ Available online 25 \\ November 2018

Kata Kunci:
CIRC, minat baca dan hasil
belajar.
Keywords:
CIRC, reading interest and
learning outcomes. \\ learning outcomes.
}

\begin{abstract}
A B S T R A K
Penelitian ini bertujuan untuk menguji 1) pengaruh model Cooperative Integrated Reading Compotition (CIRC) berbantuan Notes terhadap minat membaca, 2) pengaruh model CIRC berbantuan Notes terhadap hasil belajar pada mata kuliah Belajar dan Pembelajaran anak SD, 3) secara simultan terdapat perbedaan minat baca dan hasil belajar pada mata kuliah Belajar dan Pembelajaran Anak SD antara mahasiswa yang mengikuti metode pembelajaran CIRC berbantuan Notes dengan mahasiswa yang mengikuti pembelajaran dengan model bukan CIRC. Jenis penelitian ini adalah penelitian eksperimen semu (quasy exsperiment) dengan rancangan penelitian post-test only control group design. Populasi penelitian ini adalah mahasiswa PGSD Undiksha UPP Singaraja yang mendapatkan mata kuliah Belajar dan Pembelajaran Anak SD. Teknik pengambilan sampel yang digunakan adalah random sampling. Data dikumpulkan dengan menggunakan kuesioner dan tes. Untuk menganalisis data digunakan dua teknik analisis, yaitu analisis statistik deskriptif dan analisis infrensial. Temuan penelitian menunjukkan bahwa: 1) Terdapat pengaruh yang signifikan model
\end{abstract} pembelajaran CIRC berbantuan notes terhadap minat baca mahasiswa PGSD Undiksha UPP Singaraja. 2) Terdapat pengaruh yang signifikan model pembelajaran CIRC berbantuan notes terhadap hasil belajar mahasiswa PGSD Undiksha UPP Singaraja, dan 3) Terdapat perbedaan minat baca dan hasil belajar mahasiswa yang mengikuti proses pembelajaran dengan model pembelajaran CIRC berbantuan notes dan mahasiswa yang mengikuti pembelajaran dengan model pembelajaran selain CIRC. Dari simpulan di atas maka ada beberapa saran yang dapat disampaikan yaitu:1) Pembelajaran dengan menggunakan model CIRC berbantuan notes telah terbukti dapat meningkatkan minat baca dan hasil belajar untuk itu disarankan pada para pendidik pengajar belajar dan pembelajaran dapat mengadopsi model pembelajaran ini, 2) Bagi peneliti lain yang ingin melakukan penelitian yang sejenis, hasil penelitian ini dapat dijadikan sebagai salah satu bahan rujukan.

\begin{abstract}
A B S T RA C T
This study aims to examine 1) the influence of Notes-assisted Cooperative Integrated Reading Composition (CIRC) model on interest in reading, 2) the effect of CIRC models assisted by Notes on learning outcomes in Elementary School Learning and Learning subjects, 3) simultaneously there are differences in reading and learning outcomes in Elementary School Learning and Learning courses between students who follow the CIRC learning method assisted with Notes with students who take part in learning with models not CIRC. This type of research is quasi experiment with a post-test only control group design. The population of this study was the students of PGSD Undiksha UPP Singaraja who took the course of Learning and Instructions of Elementary School. The sampling technique used is random sampling. The data was collected using questionnaires and tests. To analyze the data used two analysis techniques, namely descriptive statistical analysis and non fractional analysis. The research findings show that: 1) There is a significant effect of the CIRC learning model assisted by notes on the reading interest of PGSD Undiksha UPP Singaraja students. 2) There is a significant effect of the CIRC learning model assisted with notes on the learning outcomes of the UPP Singaraja Undiksha PGSD students, and 3) There are differences in reading interest and learning outcomes of students who took part in the learning process with CIRC learning models assisted by notes and
\end{abstract}


students who follow learning with learning models besides CIRC. From the conclusions above, there are several suggestions that can be conveyed, those are: 1) since the learning using CIRC model assisted by notes has been proven to increase reading interest and learning outcomes so it is suggested that educators can adopt this learning model in their teaching, 2) for other researchers who want to conduct similar research, the results of this study can be used as one of the reference materials.

Copyright (C) Universitas Pendidikan Ganesha. All rights reserved.

\section{Pendahuluan}

Keberhasilan belajar seorang mahasiswa dengan mahasiswa yang lainnya berbeda-beda, hal ini bisa disebabkan oleh beberapa faktor. Fator tersebut antara lain: faktor internal, faktor eksternal, dan faktor pendekatan belajar. Faktor internal merupakan faktor yang berasal dari diri sendiri terdiri dari aspek fisiologis dan aspek psikologis. Aspek fisiologis meliputi kondisi jasmani sedangkan aspek psikologis meliputi intelegensi, sikap, bakat, minat dan motivasi. Faktor yang berasal dari luar diri siswa antara lain lingkungan sosial, lingkungan non-sosial, metode pembelajaran, dan media pembelajaran. Sedangkan faktor pendekatan pembelajaran merupakan jenis upaya belajar yang meliputi strategi dan metode yang digunakan untuk melakukan kegiatan pembelajaran.

Salah satu pendekatan yang dilakukan oleh seseorang untuk memperoleh keberhasilan dalam belajara adalah membaca. Pada dasarnya keterampilan membaca sangat memegang peran penting dalam kehidupan manusia, karena pengetahuan apapun tidak terlepas dari membaca. Tanpa memiliki keterampilan tersebut, maka pengetahuan yang akan diberikan tidak berarti, mengingat saat ini merupakan era globalisasi yang banyak menuntut berbagai keterampilan, utamanya membaca dan menulis.

Belajar dan pembelajran anak SD adalah salah satu mata kuliah keahlian dimana mahasiswa dituntut untuk memahami apa itu belajar dan pembelajaran dan mampu mengaplikasikannnya baik dalam lingkup pendidikan sekolah maupun di masyarakat. Mata kuliah belajar dan pembelajarn anak SD ini lebih menuntut mahasiswa untuk banyak membaca buku yang berkaitan dengan mata kuliah ini dan berdiskusi dengan kelempok.

Akan tetapi dari hasil observasi yang dilakukan dibeberapa kelas hampir 75\% mahasiswa mempunyai minat membaca yang minim. Mereka membaca hanya saat ditugaskan itupun membaca hanya untuk menjawab soal atau mengerjakan tugas. Gaya membaca seperti ini akan membuat mahasiswa hanya tahu sebagian kecil dari apa yang diharapkan dan tujuan dari mata kuliah ini tidak tercapai. Dengan kata lain hasil belajar yang diharapkan tidak optimal.

Pemilihan model pembelajaran harus memperhatikan kondisi siswa, sifat materi bahan ajar, fasilitas media yang tersedia dan kondisi guru (Uno, 2011:105). Dengan demikian proses pembelajaran akan variatif, inovatif dan konstruktif yang nantinya dapat menciptakan suatu interaksi antara dosen dengan mahasiswa, mahasiswa dangan mahasiswa maupun mahasiswa dengan sumber-sumber belajar lainnya. Salah satu model pembelajaran yang dapat diterapkan guna meningkatkan minat baca adalah Model Cooperative Integrated Reading Compotition (CIRC).

Menurut Abidin (2012:93) pembelajaran yang menggunakan model CIRC membawa konsep pemahaman inovatif sehingga dapat mengoptimalkan hasil belajar. Model pembelajaran CIRC membuat peserta didik termotivasi pada proses pembelajaran, karena bekerja dalam kelompok. Peserta didik tidak hanya mengharapkan bantuan dari pengajar saja tetapi juga mendapat bantuan dari teman sebaya, serta peserta didik juga dapat termotivasi untuk belajar cepat, akurat, dan dapat mencapai ketuntasan belajar dalam seluruh materi. Model CIRC adalah komposisi terpadu membaca dan menulis secara kooperatif kelompok (Suyatno, 2009:68).

Menurut Lasmiati, (2011) bahwa CIRC merupakan sebuah program komprehensif yang luas dan lengkap untuk pengajaran membaca dan menulis untuk kelas-kelas tinggi sekolah dasar. Model pembelajaran CIRC ini dikategorikan sebagai pembelajaran terpadu, dimana setiap peserta didik bertanggung jawab terhadap tugas kelompok saling mengeluarkan ide-ide untuk memahami suatu konsep.

Model CIRC merupakan pembelajaran yang muncul dari konsep bahwa peserta didik akan lebih mudah menemukan dan memahami konsep yang sulit jika mereka saling berdiskusi dengan temannya. Hal tersebut menunjukkan bahwa aktivitas peserta didik dalam bentuk diskusi sangat menentukan keberhasilanya dalam memahami segala konsep dalam pembelajaran. Dalam bentuk kelompok kecil peserta didik saling membantu memecahkan masalah yang ada. Pemahaman peserta didik akan menjadi kuat karena mereka sendiri yang menemukannya melalui diskusi. 
Penelitian ini dikuatkan oleh penelitian sebelumnya yang dilakukan oleh Sando (2013) Menyatakan Bahwa, Berdasarkan hasil analisis data dan pengujian hipotesis yang telah dilakukan dapat disimpulkan: (1) Ada hubungan yang positif dan signifikan antara lingkungan belajar dengan prestasi belajar siswa, berarti semakin baik lingkungan belajar siswa maka prestasi belajar siswa akan meningkat. (2) Ada hubungan yang positif dan signifikan antara minat membaca dengan prestasi belajar siswa, berarti semakin tinggi minat membaca siswa maka akan tinggi pula prestasi belajar siswa. Dwi Watoyo. 2012. Ada hubungan yang positif antara lingkungan belajar dan minat membaca secara bersama-sama dengan prestasi belajar mata pelajaran Akuntansi siswa kelas XI jurusan IPS SMA Negeri I Paninggaran Kabupaten Pekalongan. Hal ini terbukti dari hasil analisis korelasi Product Moment pada taraf signifikasi $5 \%$ yang diperoleh Fregresi $>$ Ftabel atau 4,29 > 3,21. Model hubungan dari variabel yang dimaksud adalah : $\mathrm{Y}=43,55+0,120 \mathrm{X} 1+0,145 \mathrm{X} 2$. Hal senada juga diungkapkan oleh Maryati (2015) Menyatakan bahwa, penelitian ini menggunakan metode observasi, angket dan dokumentasi, serta analisis data menggunakan analisis korelasi baik korelasi sederhana maupun korelasi ganda. Hasil analisis data menunjukan bahwa (1) terdapat hubungan yang signifikan antara lingkungan belajar dengan hasil belajar Matematika dengan koefisiensi korelasi sebesar 0,684, (2) terdapat hubungan yang signifikan antara minat membaca dengan hasil belajar Matematika dengan koefisiensi korelasi sebesar 0,670, (3) terdapat hubungan yang signifikan antara lingkungan dan minat membaca dengan hasil belajar Matematika dengan koefisiensi sebesar 0,710. Yuli Setya Hartanti (2015) menyatakan bahwa, Berdasarkan penelitian dan hasil analisis yang telah dilakukan peneliti, maka dapat disimpulkan bahwa: (1) Kecenderungan minat membaca siswa dengan skor ratarata 47,25 berada pada interval 40,5 $<\rangle^{-} 49,5$ sehingga dapat disimpulkan bahwa kecenderungan minat membaca siswa pada mata pelajaran matematika siswa kelas X jurusan akuntasi SMK sekecamatan Kalibawang termasuk dalam kategori sedang. (2) Kecenderungan lingkungan belajar dengan skor rata- rata 37 berada pada interval 31,5< $<\geq 38,5$ sehingga dapat disimpulkan bahwa kecenderungan lingkungan belajar siswa kelas X jurusan akuntasi SMK sekecamatan Kalibawang termasuk dalam kategori sedang; (3) Kecenderungan prestasi belajar matematika dengan nilai rata- rata 66,5 berada pada interval $56,09<\dot{*} \geq 68,27$ sehingga dapat disimpulkan bahwa kecenderungan prestasi belajar matematika siswa siswa kelas X jurusan akuntasi SMK sekecamatan Kalibawang termasuk dalam kategori tinggi

Selain dengan berdiskusi, untuk membatu peserta didik lebih lama mengingat materi digunakan catatan kecil (Notes), dengan menggunakan catatan kecil mahasiswa bisa menulis hal-hal penting yang ditemukan dalam bacaan. Tidak semua hal yang kita baca atau dengarkan dapat diingat oleh karena itulah perlu dicatat dalam sebuah catatan kecil (Notes). Dengan membuat catatan kecil dapat melatih indra pendengaran dan otak untuk saling bekerja sama.

Berdasarkan uraian di atas, penggabungan model CIRC berbantuan Notes dapat diprediksi dapat memecahkan permasalahan minat membaca peserta didik serta dapat mengoptimalkan pencapaian hasil belajar. Dengan demikian, penelitian untuk memverifikasi pengaruh model CIRC berbantuan Notes dilakukan terhadap mahasiswa calon guru SD yaitu mahasiswa PGSD Undiksha UPP Singaraja pada mata kuliah Belajar dan Pembelajran Anak SD.

\section{Metode}

Penelitian yang dilakukan ini adalah penelitian quasi experiment, dengan rancangan post test only control group design. Populasi penelitian adalah mahasiswa S1 PGSD Undiksha UPP Singaraja yang memperoleh mata kuliah Belajar dan Pembelajaran Anak SD sejumlah 260 orang (6 kelas). Berdasarkan karakteristik populasi yang tidak bisa dilakukan pengacakan individu, maka pengambilan sampel dilakukan dengan tehknik group random sampling. Variabel bebas dalam penelitian ini adalah model pembelajaran CIRC berbantuan Notes. Sebagai variabel terikat dalam penelitian ini adalah minat baca dan hasil belajar pada mata kuliah Belajar dan Pembelajaran Anak SD.

Data yang dikumpulkan dalam penelitian ini adalah minat baca yang dikumpulkan dengan kuesioner dan hasil belajar pada mata kuliah Belajar dan Pembelajaran anak SD dikumpulkan dengan tes. Data dianalisis dengan menggunakan dua teknik analisis yaitu analisis deskriptif dan analisis infrensial. Data dianalisis dengan MANOVA. Sebelum melakukan analisis data infrensial, maka data yang diperoleh diuji terlebih dahulu normalitas dan homogenitasnya. UJi normalitas dengan menggunakan SPSS-17.00 for windows uji statistik Kolmogorov-Smirnov pada signifikansi 0,05. Kriteria pengujian data memiliki matriks varians-kovarian yang sama (homogen) jika signifikansi yang dihasilkan dalam uji Box's M dan uji Levene's lebih dari 0,05 dan data tidak berasal dari populasi yang homogen jika signifikansi yang dihasilkan dalam uji Box's M dan uji Levene's kurang dari 0,05. Pengujian homogenitas dan normalitas dilakukan menggunakan SPSS-17.00 for windows. 


\section{Hasil dan Pembahasan}

Data dalam penelitian ini dikelompokkan menjadi: 1) minat baca mahasiswa yang mengikuti model CIRC berbantuan Notes, 2) hasil belajar mahasiswa yang mengikuti model CIRC berbantuan Notes, 3) minat baca mahasiswa yang mengikuti Model selain CIRC berbantuan Notes, dan 4) hasil belajar Mahasiswa yang mengikuti model selain CIRC berbantuan Notes.

Tabel 1. Rekapitulasi Hasil Perhitungan Skor minat baca dan hasil belajar pada mata kuliah Belajar dan Pembelajaran Anak SD.

\begin{tabular}{lcccc}
\hline \multirow{2}{*}{$\begin{array}{l}\text { Variabel } \\
\text { Statistik }\end{array}$} & \multicolumn{2}{c}{ Minat baca } & \multicolumn{2}{c}{ Hasil belajar } \\
\cline { 2 - 5 } & Eksperimen & Kontrol & Eksperimen & Kontrol \\
\hline Mean & 80,1 & 67,8 & 83,4 & 68,6 \\
Median & 80,0 & 68,0 & 83,0 & 69,0 \\
Modus & 80,0 & 72,0 & 83,0 & 75,0 \\
Std. Deviasi & 6,5 & 5,3 & 6,23 & 75,0 \\
Skor Minimum & 69,0 & 57,0 & 73 & 55,0 \\
Skor Maksimum & 90,0 & 75,0 & 95 & 80 \\
\hline
\end{tabular}

Berdasarkan tabel di atas, dapat diketahui rata-rata (mean), median dan modus skor minat baca dan hasil belajar baik pada kelompok eksperimen maupun kelompok kontrol. Berdasalkan hasil yang disajikan pada tabel 1 di atas dapat mengindikasikan bahwa secara deskriptip model CIRC member pengaruh yang lebih baik pada minat baca dan hasil belajar mahasiswa pada mata kuliah Belajar dan pembelajaran anak SD. Selanjutnya secara statistic dilakukan pengujian untuk membuktikan pengaruh model pembelajaran CIRC terhadap minat baca dan hasil belajar mahasiswa pada mata kuliah belajar dan pembelajaran anak SD. Sebelum dilakukan pengujian secara ststistik terlebih dahulu dilakukan pengujian asumsi.

Pengujian asumsi dilakukan untuk mengetahui bahwa data yang tersedia dapat dianalisis dengan parametric atau tidak. Berkaitan dengan statistik yang digunakan untuk analisis data dalam penelitian ini, uji asumsi yang dilakukan meliputi uji normalitas, uji homogenitas, dan uji korelasi antar variable.

Pengujian normaliats dilakukan untuk menyakinkan bahwa sampel berasal dari populasi yang berdistribusi normal, sehingga uji hipotesis dapat dilakukan. Uji normalitas data dalam penelitian ini menggunakan statistic Kolmogorov-Swirnov test (Candiasa, 2007) dengan bantuan SPSS V.19 for Windows. Hasil analisis mengunakan statistic Kolmogorov-Swirnov test disajikan pada Tabel 2.

Tabel 2. Hasil Uji Normalitas Sebaran Data

\begin{tabular}{cccccccc}
\hline & \multirow{2}{*}{ GROUP } & \multicolumn{3}{c}{ Kolmogorov-Smirnov } & \multicolumn{3}{c}{ Shapiro-Wilk } \\
\cline { 3 - 8 } & & Statistic & $\mathrm{df}$ & Sig. & Statistic & $\mathrm{df}$ & Sig. \\
\hline \multirow{2}{*}{ MINAT BACA } & 1 & 0,131 & 35 & 0,133 & 0,942 & 35 & 0,065 \\
& 2 & 0,146 & 35 & 0,058 & 0,941 & 35 & 0,058 \\
HASIL BELAJAR & 1 & 0,083 & 35 & $0,200^{*}$ & 0,970 & 35 & 0,449 \\
& 2 & 0,136 & 35 & 0,097 & 0,51 & 35 & 0,121 \\
\hline
\end{tabular}

Berdasarkan data dari tabel di atas, nilai statistic Kolmogorov-Smirnnov untuk motivasi belajar lebih besar dari 0,05. Sehingga dapat disimpulkan bahwa kelompok data minat baca berdistribusi normal. Begitu juga dengan nilai statistic Kolmogorov-Smirnnov untuk hasil belajar lebih besar dari 0,05. Sehingga dapat disimpulkan bahwa kelompok data hasil belajar berdistribusi normal. Sehingga uji selanjutnya dapat dilanjutkan.

Uji homogenitas varians antar kelompok digunakan untuk mengukur apakah group mempunyai varians yang sama antara group tersebut. Uji homogenitas varians antar kelompok menggunakan uji Levene's yang dilakukan terhadap empat kelompok data. Untuk uji analisis homogenitas melalui uji Levene's disajikan pada Tabel 3. 
Tabel 3. Hasil uji analisis homogenitas melalui uji Levene’s

\begin{tabular}{lcccc}
\hline & F & df1 & df2 & Sig. \\
\hline Minat Baca & 2,055 & 1 & 68 & 0,156 \\
Hasil Belajar & 2,470 & 1 & 68 & 0,121 \\
\hline
\end{tabular}

Berdasarkan hasil dari data tabel di atas, tampak bahwa semua nilai statistic Levene's menunjukkan angka signifikan lebih dari 0,05, baik data skor minat baca maupun data nilai hasil belajar Belajar dan Pembelajaran. Hal ini berarti varian antara kelompok eksperimen dan kelompok kontrol adalah homogen, baik untuk data skor minat baca maupun skor nilai hasil belajar. Selain nilai statistic Levene's diperlukan untuk uji hifotesis dengan manova juga dilakukan uji homogenitas matriks varian/covarian dilihat dari uji Box's M. uji Box'M di sajikan pada Tabel 4 berikut.

Tabel 4. Hasil Uji Box's M

\begin{tabular}{lc}
\hline Box's M & 5,262 \\
\hline F & 1,698 \\
df1 & 3 \\
df2 & $8,323 E 5$ \\
Sig. & 0.165 \\
\hline
\end{tabular}

Dari tabel 4, ditunjukan nilai Box's M sebesar 5, 262 dengan nilai signifikansi 0,165. Karena nilai Sig. lebih besar dari 0,05, berarti matrik covarian dari variable dependen sama, maka uji manova bisa dilanjutkan. Uji korelasi antar variabel digunakan untuk mengetahui terdapat hubungan yang cukup tinggi atau tidak antara variable minat baca dangan hasil belajar mahasiswa pada mata kuliah Belajar dan Pembelajran Anak SD. Jika tidak terdapat hubungan yang cukup tinggi, maka tidak ada aspek yang sama diukur pada variable tersebut, dengan kata lain analisis dapat dilanjutkan. Teknik yang digunakan untuk menentukan multikoloniaritas adalah dengan melihat nilai VIF (variance inflation factor). Hasil analisis uji multikoloniaritas dengan nilai VIF disajikan pada Tabel 5.

Tabel 5. Hasil Analisis Uji Multikoloniaritas dengan Nilai VIF

\begin{tabular}{ccc}
\hline Model & Collinearity statistics \\
\hline & Tolerance & VIF \\
Minat Baca & 0,718 & 1,393 \\
Minat Baca & 0,718 & 1,393 \\
\hline
\end{tabular}

Dari tabel di atas dapat dilihat bahwa tidak terjadi multikolinearitas hal ini ditunjukan oleh skor dari tolerance mendekati 1 dan skor VIF mendekati 1 . Sehingga dari uji prasyarat yang telah dilakukan maka semua kelompok berasal dari populasi yang berdistribusi normal, mempunya varian yang sama atau homogeny dan tidak ada masalah multikolinieritas antar variabel. Oleh karena itu uji hipotesis dengan manova dapat dilakukan. Hasil analisis manova disajikan pada Tabel 6 berikut.

Tabel 6. Hasil Analisis Manova

\begin{tabular}{|c|c|c|c|c|c|c|}
\hline Effect & & Value & $\mathrm{F}$ & Hypothesis df & Error df & Sig. \\
\hline \multirow[t]{3}{*}{ Intercept } & Pillai's Trace & 0,997 & $9,714 \mathrm{E} 3^{\mathrm{a}}$ & 2,000 & 67,000 & 0,000 \\
\hline & Wilks' Lambda & 0,003 & $9,714 \mathrm{E} 3^{\mathrm{a}}$ & 2,000 & 67,000 & 0,000 \\
\hline & Hotelling's Trace & 289,961 & $9,714 \mathrm{E} 3^{\mathrm{a}}$ & 2,000 & 67,000 & 0,000 \\
\hline
\end{tabular}




\begin{tabular}{llrrrrr}
\hline & Roy's Largest Root & 289,961 & $9,714 \mathrm{E3}^{\mathrm{a}}$ & 2,000 & 67,000 & 0,000 \\
\hline GROUP & Pillai's Trace & 0,699 & $77,925^{\mathrm{a}}$ & 2,000 & 67,000 & 0,000 \\
& Wilks' Lambda & 0,301 & $77,925^{\mathrm{a}}$ & 2,000 & 67,000 & 0,000 \\
& Hotelling's Trace & 2,326 & $77,925^{\mathrm{a}}$ & 2,000 & 67,000 & 0,000 \\
& & & & & \\
& Roy's Largest Root & 2,326 & $77,925^{\mathrm{a}}$ & 2,000 & 67,000 & 0,000 \\
\hline
\end{tabular}

Tabel 7. Tests of Between-Subjects Effects

\begin{tabular}{llrlrrr}
\hline \multicolumn{7}{c}{ Tests of Between-Subjects Effects } \\
\hline \multirow{3}{*}{ Source } & Dependent & Type III Sum of & & & \\
Corrected Model & Variable & Squares & df & Mean Square & \multicolumn{1}{c}{ F } & \multicolumn{1}{c}{ Sig. } \\
& Minat Baca & $2629,157^{\mathrm{a}}$ & 1 & 2629,157 & 75,829 & 0,000 \\
Intercept & Hasil_Belajar & $3848,014^{\mathrm{b}}$ & 1 & 3848,014 & 80,986 & 0,000 \\
& Minat Baca & 382876,129 & 1 & 382876,129 & $1,104 \mathrm{E} 4$ & 0,000 \\
GROUP & Hasil Belajar & 404168,014 & 1 & 404168,014 & $8,506 \mathrm{E} 3$ & 0,000 \\
& Minat Baca & 2629,157 & 1 & 2629,157 & 75,829 & 0,000 \\
Error & Hasil Belajar & 3848,014 & 1 & 3848,014 & 80,986 & 0,000 \\
\multirow{5}{*}{ Total } & Minat_Baca & 2357,714 & 68 & 34,672 & & \\
\multirow{5}{*}{ Corrected Total } & Hasil Belajar & 3230,971 & 68 & 47,514 & & \\
& Minat Baca & 387863,000 & 70 & & & \\
& Hasil Belajar & 411247,000 & 70 & & &
\end{tabular}

Analisi multivariate, yang tercantum pada tabel 7 menunjukkan bahwa hubungan antara model pembelajaran $(\mathrm{X})$ dengan minat baca memberikan harga $\mathrm{F}$ sebesar 75,829 dengan signifikansi 0,00 yang lebih kecil dari taraf signifikansi 0,05 . Ini berarti hipotesis nol (Ho) yang menyatakan bahwa tidak terdapat pengaruh yang signifikan penerapan model pembelajaran CIRC berbantuan Notes terhadap minat baca mahasiswa PGSD Undiksha pada mata kuliah Belajar dan Pembelajaran Anak SD di tolak. Hal ini menunjukkan bahwa terdapat pengaruh yang signifikan model pembelajaran CIRC berbantuan Notes terhadap minat baca mahasiswa PGSD Undiksha pada mata kuliah Belajar dan Pembelajaran Anak SD.

Hubungan antara model pembelajaran (X) dengan hasil belajar memberikan harga $\mathrm{F}$ sebesar 80,986 dengan signifikansi 0,00 yang lebih kecil dari taraf signifikansi 0,05. Ini berarti hipotesis nol (Ho) yang menyatakan bahwa tidak terdapat pengaruh yang signifikan model pembelajaran CIRC berbantuan Notes terhadap hasil belajar mahasiswa PGSD Undiksha pada mata kuliah Belajar dan Pembelajaran Anak SD ditolak. Hal ini menunjukkan bahwa Terdapat pengaruh yang signifikan model pembelajaran CIRC berbantuan Notes terhadap hasil belajar mahasiswa PGSD Undiksha UPP pada mata kuliah Belajar dan Pembelajaran Anak SD. Hasil analisis data menunjukkan bahwa kelompok mahasiswa yang mengikuti model pembelajaran CIRC berbantuan Notes memperoleh hasil belajar yang lebih tinggi dibandingkan dengan mahasiswa yang belajar dengan bukan model pembelajaran CIRC berbantuan Notes.

Berdasarkan Tabel 6 di atas, tampak nilai-nilai statistic Pillai's Trace, Wilks' Lambda, Hotelling's Trace, Roy's Largest Root masing-masing dengan F = 9,714, dengan nilai signifikansi 0,00. Ini berarti hipotesis nol $\left(\mathrm{H}_{0}\right)$ ditolak. Oleh karena itu, hipotesis alternative $\left(\mathrm{H}_{1}\right)$ diterima. Secara simultan terdapat perbedaan yang signifikan minat baca dan hasil belajaran antara mahasiswa yang mengikuti model pembelajaran CIRC berbantuan Notes dan mahasiswa yang tidak mengikuti model pembelajaran CIRC berbantuan Notes pada mata kuliah Belajar dan Pembelajaran Anak SD.

Perbedan minat baca mahasiswa ini dapat dideskripsikan karena dalam proses pembelajaran yang menggunakan model pembelajaran CIRC berbantuan Notes menciptakan kondisi yang membuat mahasiswa merasa nyaman, senang dan tertarik mengikuti proses pembelajaran. Rasa nyaman, senang 
dan ketertarikan akan sesuatu yang membuat mahasiswa lebih antusias dalam proses pembelajaran. Mahasiswa dipacu untuk lebih aktif menemukan pengetahuannya sendiri melalui memebaca buku yang sudah disiapkan sebelumnya yang berkaitan dengan mata kuliah Belajar dan Pembelajaran Anak SD. Dalam proses pembelajaran mahasiswa dirangsang untuk membuat pertanyaan-pertanyaan yang berkaitan dengan materi yang dibelajarkan dengan bantuan Notes.

Model pembelajaran CIRC merupakan model yang melibatkan mahasiswa secara aktif dalam proses pembelajaran. Dalam proses pembelajaran, pengajar dapat memberikan suasana yang menarik dan menyenangkan sehingga mahasiswa memperoleh konsep baru. Model pembelajaran CIRC adalah model yang memadukan kegiatan membaca dan menulis dalam kelompok yang heterogen. Model pembelajaran CIRC dapat membantu pengajar memadukan kegiatan membaca dan menulis sebagai kegiatan integratif dalam pelaksanaan pembelajaran membaca. Pembelajaran dengan model CIRC terdiri dari tiga unsur penting yaitu: kegiatan-kegiatan dasar terkait, pengajaran langsung pelajar memahami bacaan dan seni berbahasa menulis terpadu.

Hal ini sesuasi dengan yang dinyatakan oleh Rahim (2008:28) bahwa minat baca ialah keinginan yang kuat disertai usaha-usaha seseorang untuk membaca. Seseorang yang mempunyai minat membaca yang kuat akan berusaha mendapatkan bahan bacaan kemudian membacanya atas kesadaran sendiri maupun dorongan dari luar. Wahadaniah (dalam Irma Yuliani, 2012:9) menyatakan bahwa minat baca adalah suatu perhatian yang kuat dan mendalam disertai dengan perasaan senang terhadap kegiatan membaca sehingga dapat mengarahkan seseorang untuk membaca dengan kemauannya sendiri ataupun dorongan dari luar.

Senada dengan pendapat beberapa ahli di atas, Slameto (2003:57) menyatakan komponen indikator minat dalam suatu kegiatan tertentu adalah sebagai berikut. (1) Adanya rasa senang terhadap kegiatan membaca., (2) Kepuasan terhadap aktivitas membaca yang telah dilakukan., (3) Partisipasi aktif tanpa dipaksa untuk melakukan kegiatan membaca dan, (4) Lebih menyukai kegiatan membaca. Jadi dapat disimpulkan bahwa minat baca adalah kecenderungan atau ketertarikan yang dimiliki seseorang terhadap kegiatan membaca dengan disertai perasaan senang, tanpa dipaksa, dan kecenderungan tersebut diwujudkan dengan mencari bahan bacaan maupun melakukan kegiatan membaca.

Hasil penelitian ini juga didukung oleh penelitian yang dilakukan oleh Sulistyowati menyimpilkan bahwa penerapan pembelajaran dengan CIRC berpengaruh positif terhadap kemampuan menulis siswa dimana kemampuan menulis siswa yang mengikuti pembelajaran dengan CIRC lebih baik dari pada kemampuan menulis siswa dengan metode pemberian tugas.

Dari hasil analisis deskriptif yang dilakukan dalam penelitian ini, terlihat adanya perbedaan hasil belajar antara mahasiswa yang mengikuti model pembelajaran CIRC berbantuan Notes dengan mahasiswa yang mengikuti pembelajaran selain CIRC berbantuan Notes. Perbedaan ini dapat dilihat dari nilai ratarata, nila rata-rata kelompok mahasiswa yang mengikuti model pembelajaran CIRC berbantuan Notes sebesar 83,4 sedangkang nilai rata-rata kelompok mahasiswa yang mengikuti pembelajaran selain CIRC berbantuan Notes sebesar 68,6. Perbedaan hasil belajar antara kedua kelompok didukung oleh hasil analisis manova yang dilakukan. Hasil uji manova menunjukkan harga $\mathrm{F}$ sebesar 80,986 dengan signifikansi 0,00 yang lebih kecil dari taraf signifikansi 0,05. Hal ini berarti terdapat perbedaan hasil belajar yang signifikan antara mahsiswa yang mengikuti model pembelajaran CIRC berbantuan Notes dengan mahasiswa yang mengikuti model pembelajaran selain CIRC berbantuan Notes.

Perbedan hasil belajar mahasiswa ini dapat dideskripsikan karena dalam proses pembelajaran yang menggunakan model CIRC berbantuan Notes menciptakan kondisi yang membuat mahasiswa merasa nyaman, senang dan tertarik mengikuti proses pembelajaran. Rasa nyaman, senang dan ketertarikan akan sesuatu membuat mahasiswa lebih antusias dalam proses pembelajaran.

Sudjana (2009:3) mendefinisikan hasil belajar mahasiswa pada hakikatnya adalah perubahan tingkah laku sebagai hasil belajar dalam pengertian yang lebih luas mencakup bidang kognitif, afektif, dan psikomotorik. Dimyati dan Mudjiono (2006:3-4) juga menyebutkan hasil belajar merupakan hasil dari suatu interaksi tindak belajar dan tindak mengajar. Berdasarkan pengertian hasil belajar di atas, disimpulkan bahwa hasil belajar adalah kemampuan-kemampuan yang dimiliki mahasiswa setelah menerima pengalaman belajarnya baik aspek kognitif, afektif, dan psikomotorik. Hasil belajar sebagai salah satu indikator pencapaian tujuan pembelajaran di kelas tidak terlepas dari faktor-faktor yang mempengaruhi hasil belajar itu sendiri. Sugihartono, dkk. (2007:76-77), menyebutkan faktor-faktor yang mempengaruhi hasil belajar, sebagai berikut: 1) Faktor internal adalah faktor yang ada dalam diri individu yang sedang belajar. Faktor internal meliputi: faktor jasmaniah dan faktor psikologis. 2) Faktor eksternal adalah faktor yang ada di luar individu. Faktor eksternal meliputi: faktor keluarga, faktor sekolah, dan faktor masyarakat.

Hasil penelitian ini didukung oleh penelitian yang dilakukan oleh Pratiwi dkk. (2016) bahwa ada pengaruh positif yang signifikan pada penerapan model pembelajaran CIRC terhadap hasil belajar Bahasa 
Indonesia, kemampuan membaca dan menemukan pikiran pokok bacaan. Penelitian yang dilakukan oleh Sulastriani (2014) juga menyimpilkan bahwa pembelajaran dengan CIRC dapat meningkatkan hasil belajar siswa dan juga berpengaruh terhadap prestasi dan motivasi siswa baik dari segi siswa mengajukan dan menanggapi pertanyaan maupun dari segi mengamati dan bekerjasama.

Hasil penelitian menunjukkan bahwa secara simultan terdapat perbedaan yang signifikan minat baca dan hasil belajaran antara mahasiswa yang mengikuti model pembelajaran CIRC berbantuan Notes dan mahasiswa yang tidak mengikuti model pembelajaran CIRC berbantuan Notes pada mata kuliah Belajar dan Pembelajaran

\section{Simpulan dan Saran}

Bedasarkan uraian hasil penelitian maka ada tiga simpulan yang dapat disampaikan sebagai berikut: (1)Terdapat pengaruh yang signifikan model pembelajaran CIRC berbantuan notes terhadap minat baca pada mata kuliah Belajar dan Pembelajaran Anak SD mahasiswa PGSD Undiksha UPP Singaraja. Ini dapat dilihat $\mathrm{F}$ sebesar 75,829 dengan signifikansi 0,00 yang lebih kecil dari taraf signifikansi 0,05. (2) Terdapat pengaruh yang signifikan model pembelajaran CIRC berbantuan notes terhadap hasil belajar pada mata kuliah Belajar dan Pembelajaran Anak SD mahasiswa PGSD Undiksha UPP Singaraja. Ini dapat dilihat dari F sebesar 80,986 dengan signifikansi 0,00 yang lebih kecil dari taraf signifikansi 0,05. (3) Terdapat perbedaan minat baca dan hasil belajar pada mata kuliah Belajar dan Pembelajaran Anak SD antara mahasiswa yang mengikuti proses pembelajaran dengan model CIRC berbantuan notes dan mahasiswa yang mengikuti pembelajaran dengan model pembelajaran selain CIRC. Hasil statistik Pillai's Trace, Wilks' Lambda, Hotelling's Trace, Roy's Largest Root masing-masing dengan F $=9,714$, dengan nilai signifikansi 0,000 .

Dari simpulan di atas maka ada beberapa saran yang dapat disampaikan yaitu: (1) Pembelajaran dengan menggunakan model pembelajaran CIRC berbantuan notes telah terbukti dapat meningkatkan minat baca dan hasil belajar untuk itu disarankan pada para pendidik pengajar belajar dan pembelajaran dapat mengadopsi model pembelajaran ini. (2) Bagi peneliti lain yang ingin melakukan penelitian yang sejenis, hasil penelitian ini dapat dijadikan sebagai salah satu bahan rujukan.

\section{Daftar Rujukan}

Abidin, Yunus. (2012) Pembelajaran Bahasa Berbasis Pendidikan karakter. Bandung: Refika Aditama.

Candiasa, I Made. (2004). Statistik Multivariat Petunjk Analisis dengan SPSS. Singaraja: Program Pasca Sarjana Universitas Pendidikan Ganesha .

Dimyati dan Mudjiono. (2006). Belajar dan Pembelajaran. Jakarta: Rineka Cipta.

Dwi Watoyo. 2012. Hubungan Antara Lingkungan Belajar Dan Minat Membaca Siswa dengan Prestasi Belajar Mata Pelajaran Akuntansikelas Xi Jurusan IPS SMA Negeri I Paninggaran kabupaten Pekalongan Tahun 2008. JPG (Jurnal Penelitian Geografi) Unila. Vol 1, No. 3.

Maryati. 2015. Hubungan Antara Lingkungan dan Minat Membaca Dengan Hasil Belajar Matematika Siswa. Jurnal Keguruan dan Ilmu Pendidikan Universitas Lampung. Volume 5, Nomor 2.

Pratiwi Fitri Yuliati, Satrijono Haris, dan Sihono (2016) Pengaruh penerapan model pembelajaran CIRC terhadap hasil belajar bahas a indonesia pada kemampuan membaca menemukan pikiran pokokbacaan siswa kelas IV SDN Manampu 03 Jember Artikel. Universitas Jember. Di akses tgl 9 April 2017

Rahim, Farida. (2007). Pengajaran Membaca di Sekolah Dasar. Jakarta: Bumi Aksara.

Sando. 2013. Hubungan antara Lingkungan Belajar dan Minat Membaca dengan Prestasi Belajar Geografi. JPG (Jurnal Penelitian Geografi) Unila. Vol 1, No. 3.

Slameto. (2003). Belajar dan Faktor-Faktor yang mempengaruhinya. Jakarta: Rineka Cipta.

Sugihartono, dkk. (2007). Psikologi Pendidikan. Yogyakarta: UNY Press.

Sulastriani. (2014) Pengaruh Metode Koopertif Tipe CIRC Terhadap Motivasi dan Prestasi Belajar Siswa 
Kelas X Ma Mu’Allimin NW Pancor. Artikel. Diakses tanggal 9 april 2017.

Suyitno, Amin. (2005). Mengadopsi pembelajaran CIRC dalam meningkatkan keterampilan siswa menyelesaikan soal cerita. Makalah. Disajikan dalam Seminar Nasional F Mipa Unesa

Uno, Hamzah. (2011). Belajar dengan Pendekatan PAIKEM. Jakarta: Bumi Aksara.

Yuli Setya Hartanti, Esti Harini. 2016. Hubungan Antara Minat Membaca dan Lingkungan Belajar dengan Prestasi Belajar Matematika. UNION: Jurnal Pendidikan Matematika. Vol 4 No 3. 